\title{
Development of Biochemical Practicum Guides Integrated Discovery Learning
}

\author{
Ucia Mahya Dewi \\ Postgraduate Program of Chemistry Education \\ Universitas Negeri Medan \\ Medan, Indonesia \\ uciamahyadewi@gmail.com
}

\author{
Marham Sitorus \\ Lecture in Postgraduate Program of Chemistry Education \\ Universitas Negeri Medan \\ Medan, Indonesia \\ marham.sitorus@gmail.com
}

\author{
Ajat Sudrajat \\ Lecture in Postgraduate Program of Chemistry Education \\ Universitas Negeri Medan \\ Medan, Indonesia \\ ajatsudrajat@gmail.com
}

\begin{abstract}
Practical guide is a learning resource that can minimize the role of lecturers, making students more active and have creative thinking and skills so that it is easier to carry out activities in the laboratory. This research was aimed to obtain Biochemistry practicum guides integrated discovery learning (DL) in the study program of Agrotechnology and to determine the feasibility of Biochemical practicum guides integrated discovery learning according to the national standards of higher education. The research design used the Research and Development (R \& D) method with model of ADDIE (analysis, design, development, implementation, and evaluation). This research is only done in the development stages of the practical guides. The feasibility of the Biochemical practicum guide was assessed descriptively based on assessment scores from expert validators as many as four chemistry lecturers. The results showed that Biochemical practicum guides integrated discovery learning in the study program of Agrotechnology in accordance with national standards of higher education with an average value from expert validators for feasibility of content 3.83 , feasibility of language 3.81 , feasibility of presentation 3.91 and feasibility of graphic 3.91.
\end{abstract}

Keywords—biochemical, discovery learning, practical guides

\section{INTRODUCTION}

Chemistry is a science that develops through lab work processes in the laboratory to produce scientific attitudes of students. Through practical activities can provide direct experience as learning outcomes meaningful and arouse interest in learning and provide evidence for the truth of the theory that students have learned by doing practicum [1]. Through the laboratory work, the student's argument can be well developed [2].

The learning process through practical activities will run in accordance with the expected goals if the supporting factors in the activity are fulfilled, one of them is the practical guide. There needs to be instruction from the lecturer and a practicum guide that can be used to carry out practical activities [3]. Practical guide is a learning resource provided by lecturers to students to be able to learn and work well directed and continuous [4].

Biochemistry is one of the subjects that is difficult for students to comprehensively understand [5]. According to Reid \& Shah [6], the working principles of effective laboratory in higher education in which (1) integrative, (2) efficient, and (3) practical, (4) able to train students' ability in terms of developing hypotheses, solving problems, using knowledge and skills in different situations, designing a simple research to prove the hypothesis, using laboratory skills in carrying out experiments, interpreting experimental data, clearly explaining the experimental results, and recalling the critical ideas based on experimental results in the long term The formation of the concept in the long term shows the learning process has been established effectively [7].

Based on the results of field studies to students of study programs of agrotechnology available practicum guides are incomplete. Students do practicum without good preparation, in the form of theoretical or conceptual knowledge. Lab results are made in the report but not discussed, this does not provide an opportunity for students to communicate and discuss what is obtained through practicum. Each experiment begins with pretest and reporting activities, but students do not know the practical truth that has been carried out because there is no evaluation after practicum. In addition, the practical guide used does not contain scientific concepts related to problems in the environment using technology that is made to benefit society.

One model that can be integrated into a practical guide is discovery learning. Discovery learning models are suitable to be integrated into biochemical practical guides because discovery learning models can develop active student learning methods by finding information themselves so that the results 
obtained are not easily forgotten by students [8]. In addition, the integration of discovery learning models on practical guides can increase the effectiveness of practicum implementation [9].

The objective of this study is to obtain Biochemistry practicum guides integrated discovery learning in study the program of Agrotechnology and to determine the feasibility of Biochemical practicum guides integrated discovery learning according to the national standards of higher education.

\section{METHOD}

The method used is research and development. development using the ADDIE model which includes several stages of Analysis, Design, Development, Implementation, and Evaluation. This research was only carried out until the development stage and the feasibility test of practicum guidance. The types of data obtained in this research are qualitative and quantitative data. Qualitative data are comments, suggestions or criticisms of the practicum guide development. While the quantitative data in the form of numbers obtained based on the validation sheet of practicum guide using the Likert scale $(4,3,2,1)$. The data collection instrument used in this research is a validation sheet of practicum guide based on standard SNPT. The data analysis technique used to the validation result data of practicum guide is the average calculation technique.

\section{RESULTS AND DISCUSSION}

Analysis phase, carried out literature studies and field studies. Field studies include direct observation, interviews with lecturers of biochemical course, the analysis of existing guidebooks or have been used in the learning process, analysis of the material. This stage also analyzes the practical guide which has been used based on SNPT which includes several aspects, namely (1) content feasibility; (2) language feasibility; (3) the feasibility of presentation and (4) physical appearance. From the results of the analysis that has been carried out there are still many shortcomings of biochemical practical guides used by students study programs of Agrotechnology. First, the practical guide available is not in accordance with the material contained in the syllabus. Second, the practicum approach used today is a conventional practicum approach, which only provides tools, materials and work procedures. third, there is no theoretical basis and questions about the results of the experiments that have been carried out. This shows that practicum activities carried out have not provided full opportunities to students to actively participate, and lack the ability to practice thinking skills to obtain knowledge and concepts independently in order to improve student learning outcomes in terms of cognitive and skills.

The design phase aims to prepare and produce Biochemical practicum guides integrated discovery learning as an effort to improve student learning outcomes. The characteristics of the Biochemistry practicum guide integrated discovery learning that are developed include title and purpose, stimulation, problem identification, data collection consists of tools and materials, data processing in the form of observations, proof of conclusions and library references.

The next stage is the development stage. The development of integrated biochemical practicum guides on discovery learning is based on the results of the analysis conducted. The discovery learning model was chosen because it can complement all the components that did not yet exist in the guidance of the previous Biochemistry practicum.

After developing Biochemical practicum guides integrated discovery learning, the next step is to conduct a feasibility test for the practical guide by giving a questionnaire to the lecturer as a validator. due diligence includes several aspects, namely (1) feasibility of content ; (2) feasibility of language; (3) feasibility of presentation and (4) feasibility of graphics.

The results of the assessment of the feasibility Biochemistry practicum guide integrated discovery learning based on the aspect of content feasibility can be seen in Figure 1 .

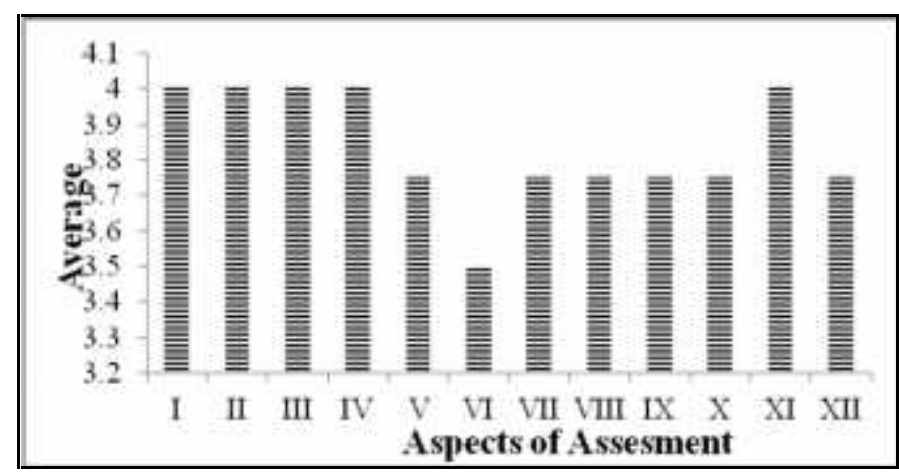

Fig 1. Result of validation feasibility of content biochemical practical guides integrated discovery learning

Information :

I : Compatibility of contents with syllabus

II :Suitability of practicum sequence with learning outcomes

III : Clarity Instructions for using practicum

IV : Practical activities according to purpose

V : Grow curiosity

VI : Stimulate thinking further

VII : Update

VIII : Stimulation according to the experiment

IX : Identify problems according to the experimental activities

$\mathrm{X}$ : Collecting data according to the purpose of the experiment

XI : Data processing

XII : Proof according to experiment

The feasibility aspect of content Biochemistry laboratory practical guides integrated discovery learning has 12 components of assessment Based on the assessment aspects of the results of the feasibility test the contents of the Biochemical practicum guide integrated discovery learning has an average of 3.83, which means it is worthy of use. 
The results of the assessment of the feasibility of the Biochemical practicum guide integrated discovery learning based on aspects of language feasibility can be seen in Figure 2.

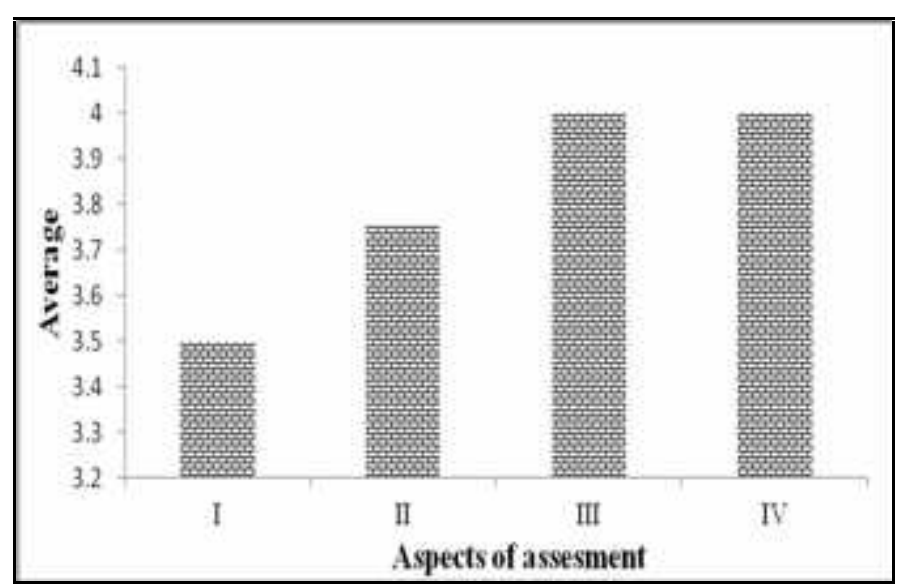

Fig 2. Result of validation feasibility of language biochemical practical guides integrated discovery learning

Information:

I : : According to the development of student thinking

II : Communicative Language

III : Accuracy of sentence structure

IV : The sentence does not have a double meaning

The feasibility aspect of language Biochemistry practicum integrated discovery learning has 4 components of assessment. Based on the assessment aspects of the results of the feasibility test of the Biochemistry practicum language integrated discovery learning has an average of 3.81 which means it is worthy of use.

The results of the assessment of the feasibility of the Biochemical practicum guide integrated discovery learning based on the aspects of the feasibility of presentation can be seen in Figure 3.

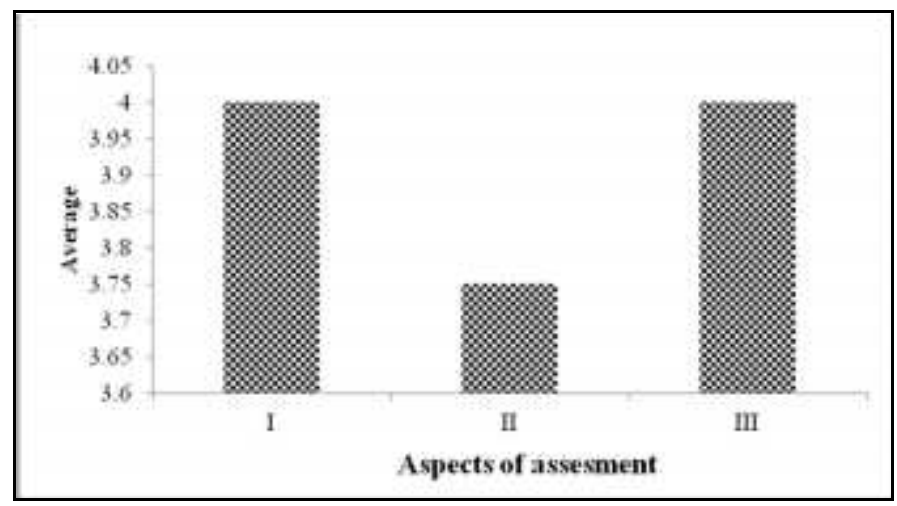

Fig 3. Result of validation feasibility of presentation biochemical practical guides integrated discovery learning

Information:

I : : Completeness of practicum guidance components

II $\quad$ : Coherent and correct work procedures
III

\section{: Completeness of supporting practical guide}

The feasibility aspect of presenting Biochemistry practical guide integrated discovery learning has 3 components of assessment Based on the aspect of assessment of the results of the feasibility test the presentation of Biochemical practical guides integrated discovery learning has an average of 3.91 which means it is worthy of use.

The results of the assessment of the feasibility of the Biochemical practicum guide integrated discovery learning based on the feasibility of graphic can be seen in Figure 4.

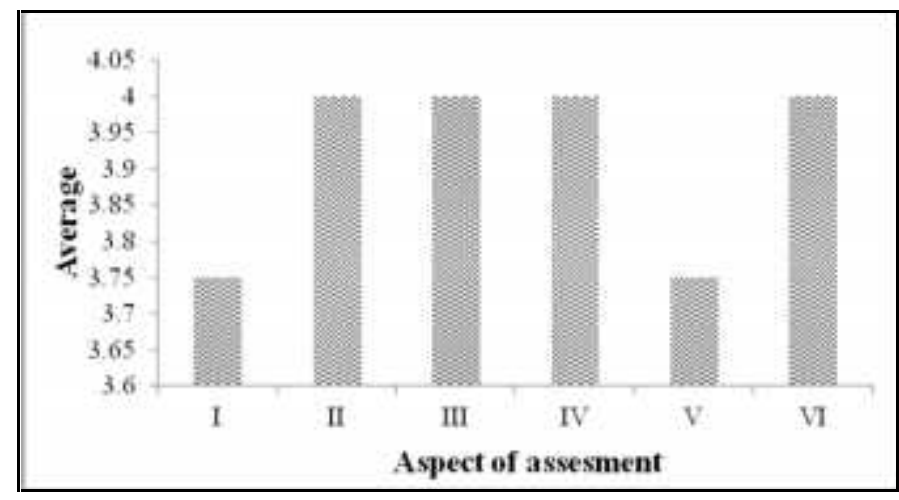

Fig 4. Result of validation feasibility of graphic biochemical practical guides integrated discovery learning

Information:

I: Clarity of identity of practical guide

II: Attractive cover design

III: The color of the cover is attractive

IV: Regular page design

V: Good and regular design

VI: Writing and images are clearly easy to read

Feasibility aspects of graphic Biochemistry practicum guide integrated discovery learning have 6 components of assessment. Based on the assessment aspects of the feasibility test results of the Biochemistry practicum guide integrated discovery learning has an average of 3.91 which means it is worthy of use

The components contained in the Biochemical practicum guide integrated discovery learning compared to the Biochemistry practicum guide used at the University can be seen in the table 1. 
TABLE 1. COMPARISON OF THE BIOCHEMISTRY PRACTICUM GUIDE INTEGRATED DISCOVERY LEARNING WITH THE BIOCHEMISTRY PRACTICUM GUIDE USED AT THE UNIVERSITY

\begin{tabular}{|c|c|c|}
\hline Component & $\begin{array}{c}\text { University } \\
\text { Biochemistry } \\
\text { Practicum Guide }\end{array}$ & $\begin{array}{c}\text { Biochemical } \\
\text { practicum } \\
\text { guides } \\
\text { developed }\end{array}$ \\
\hline $\begin{array}{l}\text { Instructions for using the } \\
\text { practical guide }\end{array}$ & - & $\sqrt{ }$ \\
\hline Work rules in the laboratory & $\sqrt{ }$ & $\sqrt{ }$ \\
\hline Health and Safety (K3) & $\sqrt{ }$ & $\sqrt{ }$ \\
\hline Safety Data Sheet & - & $\sqrt{ }$ \\
\hline $\begin{array}{l}\text { Danger symbol in the } \\
\text { laboratory }\end{array}$ & - & $\sqrt{ }$ \\
\hline First aid in the laboratory & - & $\sqrt{ }$ \\
\hline Waste handling procedures & - & $\sqrt{ }$ \\
\hline Chemical laboratory equipment & - & $\sqrt{ }$ \\
\hline Practical work techniques & - & $\sqrt{ }$ \\
\hline The purpose of the experiment & - & $\sqrt{ }$ \\
\hline Basic theory & - & $\sqrt{ }$ \\
\hline Identification of problems & - & $\sqrt{ }$ \\
\hline Tools and materials & $\sqrt{ }$ & $\sqrt{ }$ \\
\hline Work procedures & $\sqrt{ }$ & $\sqrt{ }$ \\
\hline Observation table & - & $\sqrt{ }$ \\
\hline Question after practicum & - & $\sqrt{ }$ \\
\hline Practical video link & - & $\sqrt{ }$ \\
\hline Bibliography & - & $\sqrt{ }$ \\
\hline
\end{tabular}

Overall, the results of the feasibility test of the Biochemistry practicum guideline that have been developed based on the feasibility questionnaire practicum guideline that has been modified from SNPT and the suitability of the discovery learning model obtained an average score of 3.86 with very valid criteria meaning that the biochemistry practicum guideline integrated discovery learning is very feasible for used but improvements need to be done based on suggestions for improvement / comments from the validator.

\section{CONCLUSION}

Biochemical practicum guides integrated discovery learning in the study program of Agrotechnology in accordance with national standards of higher education with an average value from expert validators for feasibility of content 3.83, feasibility of language 3.81, feasibility of presentation 3.91 and feasibility of graphic 3.91 .

\section{REFERENCES}

[1] O. Christina, and G. Gunnel, "Laboratory Work : The Teachers Perspective, ” Journal of Biology, vol. 40(3), pp. 113-118, 2006.

[2] A. Hofstein, M. Kipnis, and P. Kind, "Learning in and from science laboratories: Enhancing students" meta-cognition and argumentation skills. In C. L. Petroselli (Ed.)," Science education issues and developments, pp. 59-94, London, 2008.

[3] S.K. Umah, Sudarmin and N. R. Dewi, "Pengembangan Petunjuk Praktikum IPA Terpadu Berbasisi Inkuiri Terbimbing pada Tema Makanan dan Kesehatan," Unnes Science Education Journal, vol. 3(2), pp. 511-518, Juli 2014

[4] A. Kilinc, "The Options of Turkish Highschool Pupils on Inquiry Based Laboratory Activities. Gazi University gazi Education Faculty Departement of Biology Education (online), http://www.tojet.net/articles/646.pdf. 2007.

[5] J. Varghese, M. Faith, and M. Jacob , "Impact of e-resources on learning in biochemistry: first-year medical students' perceptions BMC Medical Education," vol. 12(21), pp. 1-9, 2012.

[6] N. Reid, and I. Shah, "Chemistry Education Research and Practice," vol.8(2), pp. 172-185, 2007.

[7] S.D. Brookfield., "Teaching for critical thinking: tools and techniques to help students question their assumptions," jossey-bass a wiley imprint: p. 157, San Francisco, 2012.

[8] M. Kadri, dan M. Rahmawati, "Pengaruh Model Pembelajaran Discovery Learning Terhadap Hasil Belajar Siswa Pada Materi Pokok Suhu dan Kalor,” Jurnal Ikatan Alumni Fisika, vol.1(1), 2015.

[9] F.J. Purba, ,Z. Mukhtar, dan R. Silaban, "Pengembangan Penuntun Praktikum Kimia Sesuai Model Pembelajaran Penemuan dan Berbasis Proyek," Jurnal Penelitian Bidang Pendidikan, vol. 21(1), pp. 21-28, 2015. 